\title{
Physicochemical properties of expanded extrudates from colored sorghum genotypes
}

\author{
Jhony Willian Vargas-Solórzano a , Carlos Wanderlei Piler Carvalho ${ }^{\mathrm{b}, *}$, Cristina Yoshie Takeiti ${ }^{\mathrm{b}}$, \\ José Luís Ramírez Ascheri ${ }^{\mathrm{b}}$, Valéria Aparecida Vieira Queiroz ${ }^{\mathrm{c}}$ \\ a Universidade Federal Rural do Rio de Janeiro, Rodovia Br 465, Km 7, CEP 23890-000 Seropédica, RJ, Brazil \\ b Embrapa Food Technology, Avenida das Américas 29501, Guaratiba, CEP 23020-470 Rio de Janeiro, RJ, Brazil \\ c Embrapa Maize and Sorghum, Rodovia MG 424, Km 65, CEP 35701-970 Sete Lagoas, MG, Brazil
}

\section{A R T I C L E I N F O}

\section{Article history:}

Received 20 August 2013

Accepted 17 October 2013

Available online 26 October 2013

\section{Keywords:}

Whole grain

Condensed tannin

Functional property

Die pressure

Specific mechanical energy

\begin{abstract}
A B S T R A C T
The diversity of sorghum grains is related to their intrinsic properties, which include starch type, non-starch components and phenolic compounds. The latter are genotype dependent and affect the pericarp characteristics such as color and presence of a pigmented testa. This diversity can be valuable for developing new food products by thermoplastic extrusion intended for human consumption. Flours from sorghum grains from the genotypes of varied pericarp color: white (CMSXS180; 9010032), red (BRS 310; BRS 308) and light brown (BRS 305; 9929034 ) were processed in a co-rotating twin-screw extruder. Changes promoted by extrusion cooking were evaluated via specific mechanical energy (SME), die pressure, apparent density, sectional expansion index (SEI), water absorption index (WAI) and water solubility index (WSI). Pericarp color affected die pressure, apparent density and WSI values of extrudates. Light brown genotypes, rich in tannin and fiber content, generated the lowest die pressure and SEI values. Red genotypes presented the lowest SME and the highest WAI values. White genotypes presented intermediate SME and the highest die pressure values. These results reflect differences in starch conversion induced by the pericarp type. These results further suggest the potential use of pigmented sorghum extrudates for human consumption.
\end{abstract}

(C) 2013 Elsevier Ltd. All rights reserved.

\section{Introduction}

The production of sorghum in Brazil reached 1.93 million tons in 2011 (FAOSTAT, 2013). Despite the noticeable production of this grain, it is not included directly in the Brazilian diet, but is used for animal feeding. In Brazil, it is believed that sorghum is not consumed due to sensorial reasons (Vázquez-Araújo, Chambers Iv, \& Cherdchu, 2012). Although, the consumption of whole sorghum flour would bring health benefits, because it contains bioactive compounds such as high fiber content and phenolic compounds (phenolic acids, flavonoids and condensed tannins) (Awika \& Rooney, 2004; Dykes \& Rooney, 2006).

In recent years, sorghum was studied for human consumption using mainly thermal process (Al-Rabadi, Torley, Williams, Bryden, \& Gidley, 2011a,b; Mahasukhonthachat, Sopade, \& Gidley, 2010; Meera, Bhashyam, \& Ali, 2011; Méndez-Albores, Veles-Medina, Urbina-Álvarez, Martínez-Bustos, \& Moreno-Martínez, 2009; Moraes et al., 2012; Wu,

\footnotetext{
* Corresponding author. Tel.: +55 2136229796.

E-mail addresses: jwvargass@ufrrj.br (J.W. Vargas-Solórzano),

carlos.piler@embrapa.br (C.W.P. Carvalho), cristina.takeiti@embrapa.br (C.Y. Takeiti), jose.ascheri@embrapa.br (J.L.R. Ascheri), valeria.vieira@embrapa.br (V.A.V. Queiroz).
}

Huang, Qin, \& Ren, 2012) compared to non-thermal processing (Mukisa et al., 2012). Extrusion cooking is a continuous process in one-step that combines shear forces, high pressure and high temperature in a short time (Berk, 2009). The food material is plasticized with water to achieve fluidity and continuously cooked while traversing through a cylindrical barrel (Berrios, Ascheri, \& Losso, 2013). All granular material loses their native and organized structure to form a continuous viscoelastic mass. These order-disorder transitions result in size and shape modifications. Thus, simultaneously, starch granules and protein bodies are disrupted with fibrous material rearranged between them, which affect the functional properties of the extrudate (de Mesa-Stonestreet, Alavi, \& Gwirtz, 2012; Lai \& Kokini, 1991).

Most of the previous studies with regard to the sorghum extrusion were carried out with flours from decorticated grains of low-tannin genotypes and processed in single screw extruders (Anderson \& Jones, 1999; Falcone \& Phillips, 1988; Fapojuwo, Maga, \& Jansen, 1987), whereas sorghum of low and high-tannin contents was also processed (Youssef et al., 1990), as well as sorghum with varied amylose and moisture content (Gomez, Waniska, Rooney, \& Lusas, 1988).

The pericarp of sorghum grains differ in color, thickness, presence of a pigmented testa and affects the phenolic composition (Dykes, Seitz, Rooney, \& Rooney, 2009). Phenolic compounds may be present in free 
or esterified/etherified soluble form as well as in insoluble form, bound to cell wall constituents such as carbohydrates, proteins and fibers (Arranz \& Saura Calixto, 2010). This natural arrangement in sorghum genotypes could influence in melt crystalline polymers/glass transition amorphous polymers and consequently on the functional properties of extruded products.

The objective of this study was to compare the extrusion performance of six sorghum genotypes of differentiated pericarps and evaluate their physical chemical attributes.

\section{Materials and methods}

\subsection{Sample preparation and characterization}

Sorghum cultivars were supplied by Embrapa Maize and Sorghum (Sete Lagoas, MG, Brazil): CMSXS180 and 9010032 (white pericarp, without testa); BRS 310 and BRS 308 (red pericarp, without testa); BRS 305 and 9929034 (light brown pericarp, with testa). Whole grains of each genotype were manually cleaned to remove foreign particles, and then milled using a disc mill (DM) LM3600 (Perten Instruments $\mathrm{AB}$, Huddinge, Sweden) set to aperture 2. The moisture content (MC) of each flour was determined by drying at $105^{\circ} \mathrm{C}$ in a moisture balance MOC-120H (Shimadzu Corporation, Kyoto, Japan) and dried until attained a remaining moisture less than $0.05 \%$ (wet basis).

\subsubsection{Particle size distribution}

The particle size distribution measurement of the milled grains was carried out in a ROTAP sieve shaker RX-29-10 (W.S. Tyler, St. Albans, WV, USA) in duplicate. Seven screen sieve sizes (Newark, USA) were selected $(1.68,1.4,1.18,1,0.71,0.3$ and $0.106 \mathrm{~mm})$ and a pan, in order to obtain a normal distribution of particles from $100 \mathrm{~g}$ of sample sieved for $10 \mathrm{~min}$.

\subsubsection{Chemical composition analysis, neutral detergent fiber and phytates content}

The whole sorghum grains were grounded using a DM followed by a hammer-mill (HM) LM3100 (Perten Instruments AB, Huddinge, Sweden) fitted with a $0.8 \mathrm{~mm}$ sieve aperture. The proximate composition, neutral detergent fiber and phytates content of milled samples were determined according to the official methods of analysis of AOAC (2005), in duplicate measurements: moisture content (Method 925.09), total nitrogen (Method 2001.11, a conversion factor of 5.75 was used to convert total nitrogen to protein content), fat content (Method 945.38), ash content (Method 923.03), neutral detergent fiber (Method 2002.04) and phytates content (Method 986.11).

\subsubsection{Condensed tannins}

Condensed tannins were determined via the modified vanillin assay as described by Burns (1971) and Deshpande and Cheryan (1985) with modifications. Milled samples were defatted with petroleum ether in a disperser device T25 basic Ultra-Turrax (Ika ${ }^{\circledR}$ Werke,
Staufen, Germany) at $9500 \mathrm{rpm}$ for $3 \mathrm{~min}$. The extraction was performed using 1-6g of defatted sample, according to genotype, with $15 \mathrm{~mL}$ of $10 \%$ $\mathrm{HCl} /$ methanol $(\mathrm{v} / \mathrm{v})$ in a vortex shaker (Genie 2 Scientific Industries, Bohemia, NY, USA) for $1 \mathrm{~min}$ and then in ultrasound water bath Branson 2210 (VWR Scientific, Bridgeport, NJ, USA) for $10 \mathrm{~min}$. The mixture was kept at $4{ }^{\circ} \mathrm{C}$ for $8 \mathrm{~h}$ and then filtered. An aliquot of filtered extract was added to solutions of $4 \%$ vanillin and $10 \% \mathrm{HCl} /$ methanol (blank). After $20 \mathrm{~min}$ of reaction, the resultant colors were read on a spectrophotometer UV-1800 (Shimadzu Corporation, Kyoto, Japan) at $500 \mathrm{~nm}$. Condensed tannins were quantified using a calibration curve of catechin and results were expressed as milligram of catechin per gram of sample.

\subsection{Extrusion conditions and responses}

The extrusion was conducted using a Clextral Evolum HT25 corotating, intermeshing twin-screw extruder (Clextral Inc., Firminy, France) with screw diameter of $25 \mathrm{~mm}$, length:diameter ratio of 40:1 and ten temperature zones. The screw speed $(600 \mathrm{rpm})$, screw configuration and temperature profile were kept constant and are depicted in Fig. 1.

The front plate assembly (die) consisted of three parts: central manifold plate, distributor plate and holder-inserts plate (Fig. 1). Die pressure was measured with a pressure transducer fitted at the central manifold plate (Dynisco Instruments, Franklin, MA, USA). The holder-inserts plate had four holes, each of $3.8 \mathrm{~mm}$ in diameter and $14 \mathrm{~mm}$ in length.

Whole sorghum flours were fed into the feeding zone by a twinscrew, loss-in-weight gravimetric feeder model GRMD15 (Schenck Process, Darmstadt, Germany) at rate of $9 \mathrm{~kg} / \mathrm{h}$ and were monitored by Schenck Process Easy Serve software (Schenck Process, Darmstadt, Germany). Distilled water was injected between the first and second modular zones through a port with $5.25 \mathrm{~mm}$ internal diameter using a plunger metering pump model J-X 8/1 (AILIPU Pump Co. Ltd., China) set to compensate moisture differences in the samples and provide a final 14\% MC. The water flow of pump was calibrated prior to extrusion runs. Extrusion variables such as motor torque, die pressure, screw speed, water feed rate and temperature of the modules were recorded by a computer using the software FITSYS Plus (Clextral Inc., Firminy, France). Data was recorded after a minimum variation of torque and pressure at the die. The samples were collected over 15-20 min, placed in plastic trays and dried in a fan oven $\left(60^{\circ} \mathrm{C}\right.$ for $\left.4 \mathrm{~h}\right)$. After drying, they were sealed into plastic bags and stored at $7^{\circ} \mathrm{C}$ pending further analysis.

Specific mechanical energy (SME, $\mathrm{kJ} / \mathrm{kg}$ ) was calculated according to Fan, Mitchell, and Blanshard (1996) using Eq. (1).

$\mathrm{SME}=(\mathrm{T} \times 2 \pi \mathrm{f} \times \mathrm{n}) /(\mathrm{S}+\mathrm{W})$

Where $\mathrm{T}$ is the screw torque in $\mathrm{kJ}$ (given in \% by the software FITSYS Plus and converted to kJ multiplying to 0.1076 , provided by the manufacturer), $\mathrm{f}$ is the screw rotation frequency in $\mathrm{s}^{-1}, \mathrm{n}$ is the number of screws, $\mathrm{S}$ is the dry feed rate in $\mathrm{kg} / \mathrm{s}$ and $\mathrm{W}$ is the liquid feed rate in $\mathrm{kg} / \mathrm{s}$.

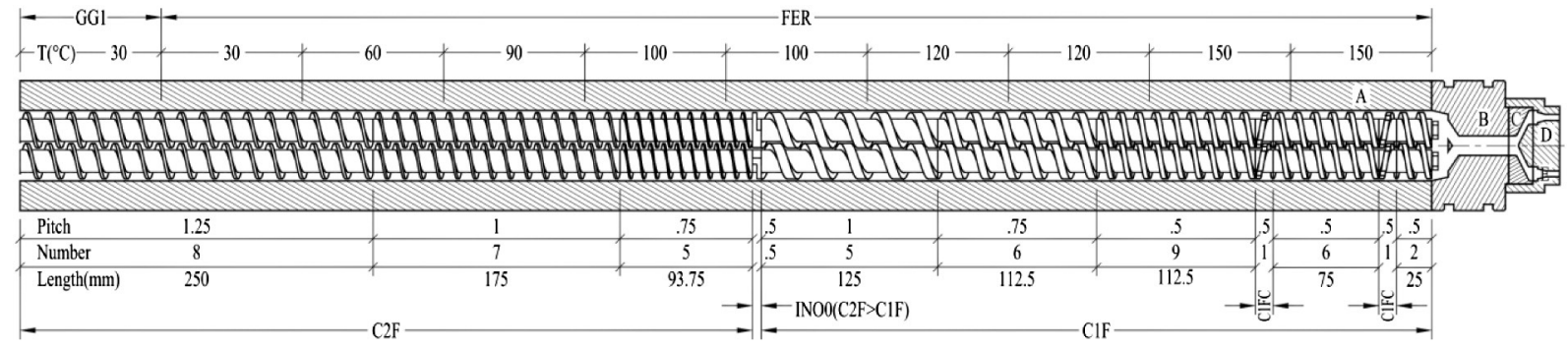

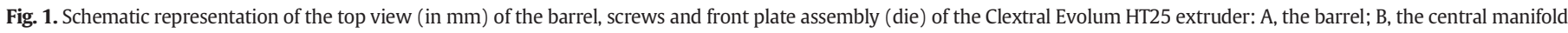

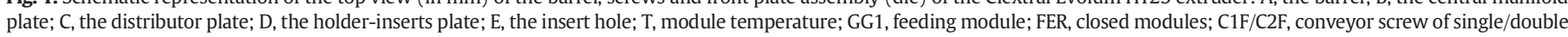
pitch; INO0, interface screw for transition between screws of single and double pitch; and C1FC, reverse screw of single pitch, slotted. 


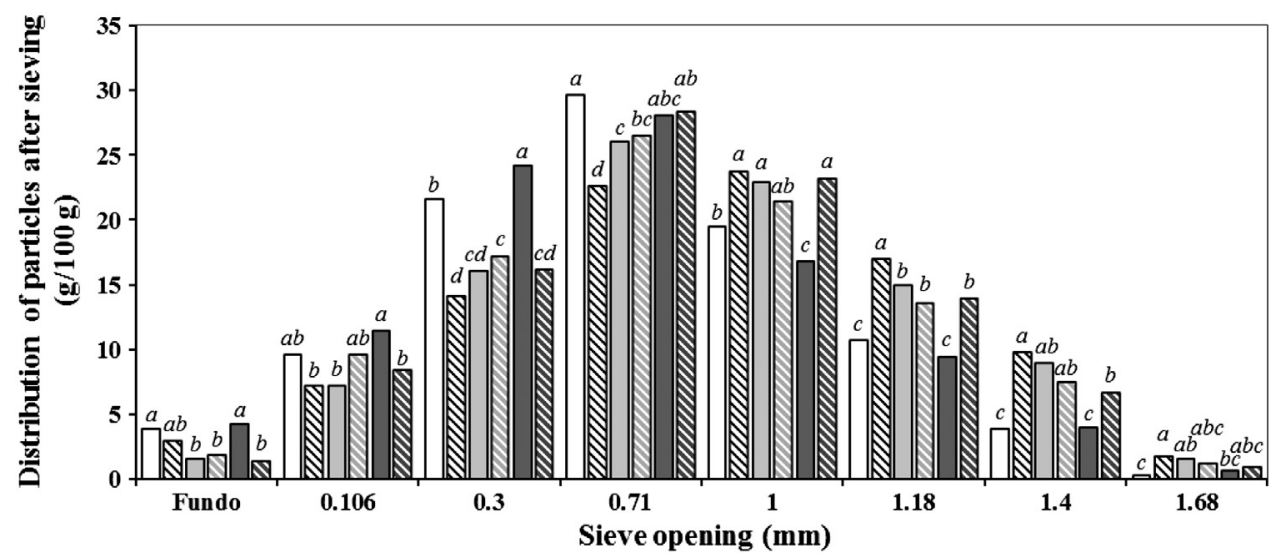

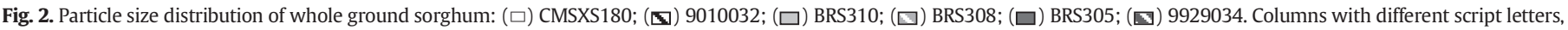
within a same sieve opening, differ from each other according to the Tukey test $(P<0.05)$.

\subsubsection{Apparent density and sectional expansion index}

Sectional expansion index (SEI) was evaluated by measuring extrudates diameter using a manual calliper of $150 \mathrm{~mm}$ (Vonder®, Curitiba, Brazil). A total of twenty readings were registered for each sample and SEI was calculated according to Eq. (2) (Alvarez-Martinez, Kondury, \& Harper, 1988).

$\mathrm{SEI}=\left(\mathrm{D} / \mathrm{D}_{0}\right)^{2}$

Where $\mathrm{D}$ is the extrudate diameter after cooling and $\mathrm{D}_{0}$ is the diameter of the insert hole. Apparent density of extrudate $(\rho)$ was calculated using Eq. (3) (Fan et al., 1996).

$\rho=(4 \mathrm{~m}) /\left(\pi \times \mathrm{D}^{2} \times \mathrm{L}\right)$

Where $\mathrm{m}$ is the extrudate mass of a length $\mathrm{L}$.

\subsubsection{Water absorption and water solubility indexes}

The extrudates were grounded using a DM followed by a HM fitted with a $0.8 \mathrm{~mm}$ sieve aperture and then sieved to obtain particles sized between 106 and $212 \mu \mathrm{m}$, which were used to determine water absorption index (WAI) and water solubility index (WSI), according to the methodology described by Anderson, Conway, Pfeifer, and Griffin (1969) with modifications. The procedure followed involved weighing $1 \pm 0.0005 \mathrm{~g}$ of sample in a test tube, adding $5 \mathrm{~mL}$ of deionized water, mixing for $20 \mathrm{~s}$ in a vortex shaker and then adding further $5 \mathrm{~mL}$ of deionized water to wash any particle adhered on the tube wall. Afterwards, the mixture was kept at $25 \pm 0.5^{\circ} \mathrm{C}$ for $30 \mathrm{~min}$ in a Dubnoff water bath NT 232 (Novatecnica, Piracicaba, SP, Brazil) to allow complete hydration. The gel formed was centrifuged at $9000 \mathrm{rpm}$
$(9961 \times g)$ at $25^{\circ} \mathrm{C}$ for $15 \mathrm{~min}$ in a centrifuge Universal 320R (Hettich, Tuttingen, Germany).

The supernatant was carefully poured into a tared evaporating dish and dried in an air circulating oven (WTB Binder, Tuttlinger, Germany) at $105^{\circ} \mathrm{C}$ for $4 \mathrm{~h}$ for total soluble solid measurement. The tube with remaining gel was superficially dried with facial tissues, and weighed. WSI and WAI analyses were conducted in triplicate and were calculated using Eqs. (4) and (5), modified by Do an and Karwe (2003).

WSI $=($ g water soluble matter $) /($ g dry sample $)$

$\mathrm{WAI}=($ g water absorbed $) /($ g dry sample $\times(1-$ soluble fraction $))$

\subsubsection{Microstructural characteristics}

Morphological observations of pericarp thickness and fractured internal radial sections of extrudates were mounted on aluminum stubs with sticky double-side conductive metal tape, without special treatment in the specimens. The samples were previously dried in an air circulating oven at $60{ }^{\circ} \mathrm{C}$ overnight. Examination was performed in a benchtop scanning electron microscope (SEM) TM3000 (Hitachi HighTechnologies Corporation, Tokyo, Japan) at $15 \mathrm{kV}$ accelerating voltage. The image acquisition was performed by TM3000 Microscope software version 02-01 (Hitachi High-Tech, Tokyo, Japan).

\subsection{Statistical analysis}

Response experimental data were assessed by analysis of variance (ANOVA) and significant differences among the means were separated by Tukey test with a value of $\mathrm{P}<0.05$.

Table 1

Proximate chemical composition, neutral detergent fiber, phytates and tannins condensed of milled grains of sorghum.

\begin{tabular}{|c|c|c|c|c|c|c|}
\hline \multirow[t]{2}{*}{ Components (g/100g) } & \multicolumn{2}{|l|}{ White pericarp } & \multicolumn{2}{|l|}{ Red pericarp } & \multicolumn{2}{|l|}{ Brown pericarp } \\
\hline & CMSXS180 & 9010032 & BRS 310 & BRS 308 & BRS 305 & 9929034 \\
\hline Moisture $^{\alpha}$ & $13.78^{\mathrm{a}} \pm 0.13^{\mathrm{a}}$ & $13.70^{\mathrm{ab}} \pm 0.11^{\mathrm{ab}}$ & $13.96^{\mathrm{a}} \pm 0.06^{\mathrm{a}}$ & $14.00^{\mathrm{a}} \pm 0.16^{\mathrm{a}}$ & $13.28^{\mathrm{bc}} \pm 0.09^{\mathrm{bc}}$ & $12.79^{c} \pm 0.24^{c}$ \\
\hline Ash & $1.73^{\mathrm{b}} \pm 0.11^{\mathrm{b}}$ & $1.83^{\mathrm{b}} \pm 0.04^{\mathrm{b}}$ & $1.76^{\mathrm{b}} \pm 0.05^{\mathrm{b}}$ & $1.71^{\mathrm{b}} \pm 0.01^{\mathrm{b}}$ & $1.59^{\mathrm{b}} \pm 0.07^{\mathrm{b}}$ & $2.47^{\mathrm{a}} \pm 0.05^{\mathrm{a}}$ \\
\hline Protein & $10.01^{\mathrm{ab}} \pm 0.16^{\mathrm{ab}}$ & $10.55^{\mathrm{a}} \pm 0.20^{\mathrm{a}}$ & $9.55^{\mathrm{b}} \pm 0.16^{\mathrm{b}}$ & $8.72^{c} \pm 0.17^{c}$ & $9.51^{\mathrm{b}} \pm 0.02^{\mathrm{b}}$ & $10.36^{\mathrm{a}} \pm 0.24^{\mathrm{a}}$ \\
\hline Fat & $3.05^{\mathrm{bc}} \pm 0.08^{\mathrm{bc}}$ & $2.75^{\mathrm{d}} \pm 0.04^{\mathrm{d}}$ & $2.96^{\mathrm{cd}} \pm 0.02^{\mathrm{cd}}$ & $3.02^{\mathrm{bc}} \pm 0.07^{\mathrm{bc}}$ & $3.32^{\mathrm{a}} \pm 0.07^{\mathrm{a}}$ & $3.18^{\mathrm{ab}} \pm 0.04^{\mathrm{ab}}$ \\
\hline Carbohydrates $^{\beta}$ & $62.52^{\mathrm{b}} \pm 0.13^{\mathrm{b}}$ & $62.34^{\mathrm{b}} \pm 0.04^{\mathrm{b}}$ & $62.96^{\mathrm{ab}} \pm 0.46^{\mathrm{ab}}$ & $64.03^{\mathrm{a}} \pm 0.31^{\mathrm{a}}$ & $59.44^{c} \pm 0.54^{c}$ & $59.61^{\mathrm{c}} \pm 0.04^{\mathrm{c}}$ \\
\hline Neutral detergent fiber & $8.93^{c} \pm 0.12^{c}$ & $8.84^{c} \pm 0.36^{c}$ & $8.83^{c} \pm 0.27^{c}$ & $8.52^{c} \pm 0.10^{c}$ & $12.86^{\mathrm{a}} \pm 0.42^{\mathrm{a}}$ & $11.58^{\mathrm{b}} \pm 0.12^{\mathrm{b}}$ \\
\hline Phytates (mg/g) & $8.72^{\mathrm{ab}} \pm 0.43^{\mathrm{ab}}$ & $7.36^{\mathrm{b}} \pm 0.11^{\mathrm{b}}$ & $7.26^{\mathrm{b}} \pm 0.45^{\mathrm{b}}$ & $7.62^{\mathrm{ab}} \pm 0.73^{\mathrm{ab}}$ & $8.02^{\mathrm{ab}} \pm 0.06^{\mathrm{ab}}$ & $9.10^{\mathrm{a}} \pm 0.29^{\mathrm{a}}$ \\
\hline Condensed tannins ( $\mathrm{mg} / \mathrm{g}$ ) & $0.64^{\mathrm{d}} \pm 0.01^{\mathrm{d}}$ & $0.64^{\mathrm{d}} \pm 0.01^{\mathrm{d}}$ & $2.04^{\mathrm{c}} \pm 0.01^{\mathrm{c}}$ & $1.98^{c} \pm 0.03^{c}$ & $13.21^{\mathrm{a}} \pm 0.08^{\mathrm{a}}$ & $5.05^{\mathrm{b}} \pm 0.15^{\mathrm{b}}$ \\
\hline
\end{tabular}

Means with different superscript letters, within a single row, differ from each other according to the Tukey test (P<0.05), to compare genotypes of sorghum flours.

$\alpha$ Mean \pm standard deviations of duplicate measurements.

$\beta$ Determined by difference. 


\section{Results and discussion}

3.1. Effect of sorghum genotype on particle size distribution and chemical composition

The particle size distribution of sorghum flours (Fig. 2) displayed reciprocal differences in amounts of fine and coarse fractions for white and brown genotypes $(\mathrm{P}<0.05)$. Differences between white genotypes probably are related to reciprocal amounts of fat and phytates content $(\mathrm{P}<0.05)$ (Table 1) and pericarp thickness, as observed in Fig. 3a,b. Only thick pericarp sorghums contain starch granules in the mesocarp (Dykes \& Rooney, 2006), which decrease the toughness of peripheral bran layers leading to an easier decortication process (Earp, McDonough, \& Rooney, 2004).

Differences in particle size distribution of brown genotypes could be associated with reciprocal amounts of tannin, protein and ash content $(\mathrm{P}<0.05)$ (Table 1$)$. It appears that more levels of condensed tannins deposited at the testa layer of brown genotypes (Fig. 3e,f) help weaken the aleurone layer and, as a result, they are easily fragmented. Aleurone layers displayed thick spherical cells of different size in all genotypes (Fig. 3). It was reported that aleurone layers are rich in ashes (Peyron,
Chaurand, Rouau, \& Abecassis, 2002). High ash content and large cells of aleurone layer observed in 9929034 grain could be related to its relative toughness. For red genotypes, it was observed similarly to the distribution of particles $(\mathrm{P} \geq 0.05)$ and displayed similar thick pericarp and peripheral endosperm area (Fig. 3c,d).

When milling process is performed at constant settings, variations of dissociation between the botanical parts of the whole grains are dependent on the ability to separate the aleurone layer from the peripheral endosperm (Peyron, Surget, et al., 2002). The cell-cell adhesion at layer interface of aleurone-endosperm was related to the degree of crosslinking of arabinoxylan chains (Peyron, Chaurand, et al., 2002). Another factor associated with mechanical properties of sorghum grains could be related to the distribution of endosperm proteins: kafirins and glutelins. Sullins and Rooney (1975) reported more protein distribution in the peripheral than in the floury endosperm region, when amylopectin/amylose ratio decreases.

\subsection{Effect of sorghum genotype on extrusion parameters}

Specific mechanical energy (SME) and die pressure were significantly affected by the sorghum genotypes $(\mathrm{P}<0.05)$ (Fig. 4a,b).
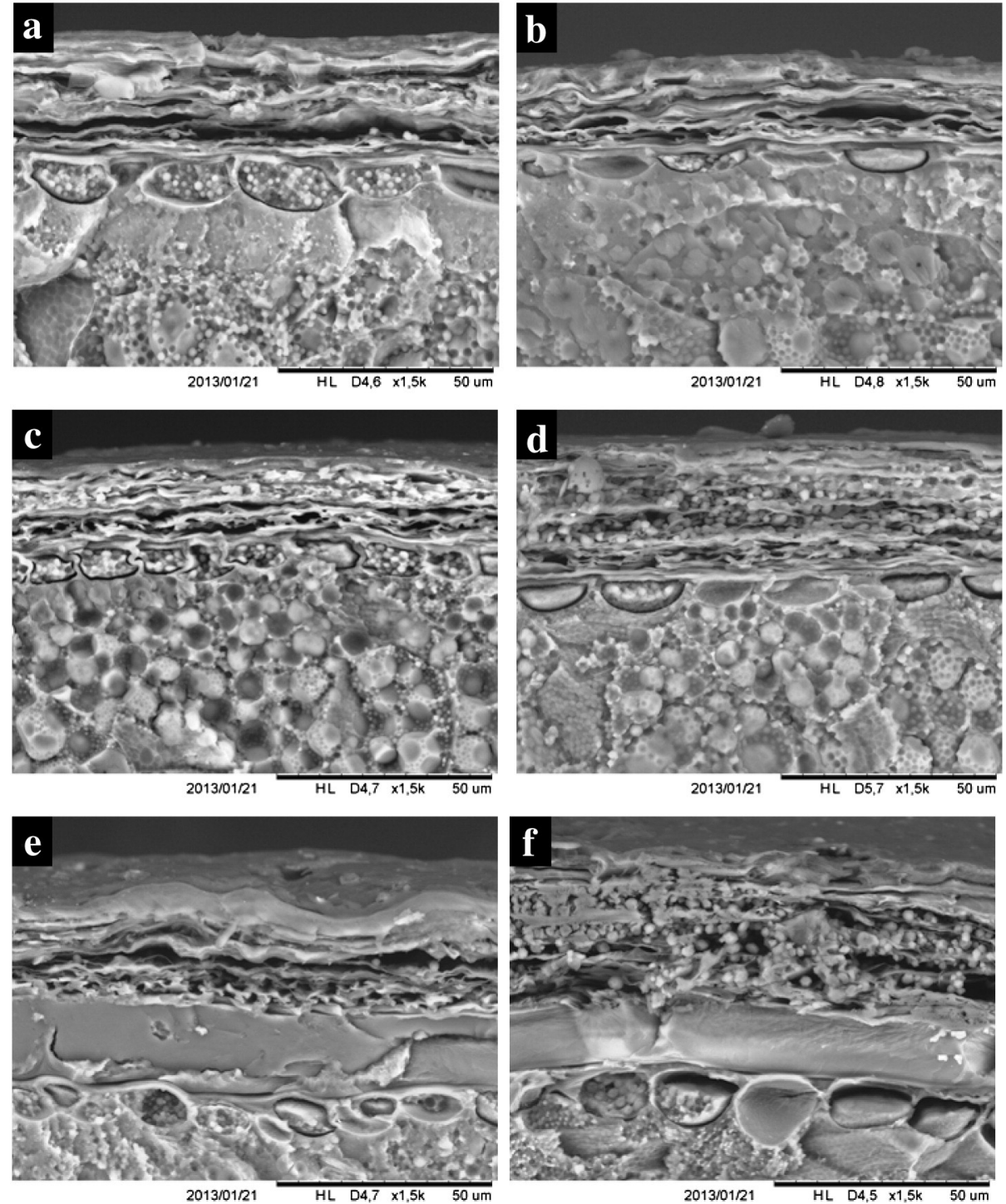

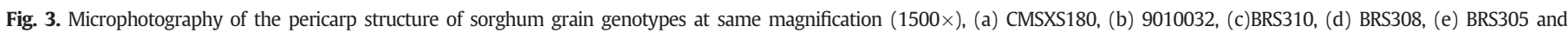
(f) 9929034 . 

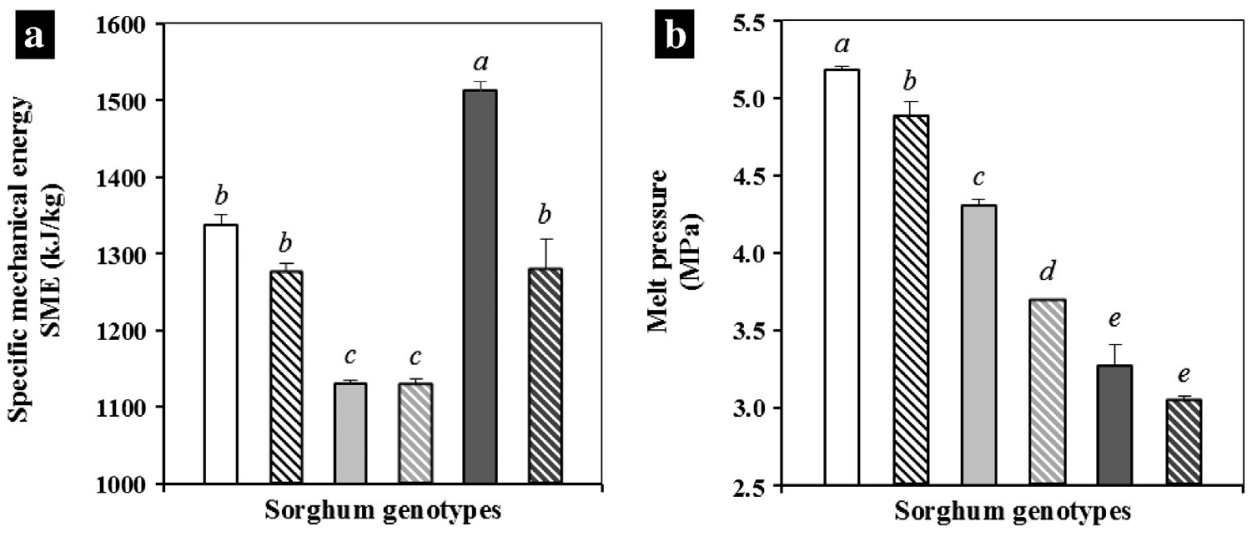

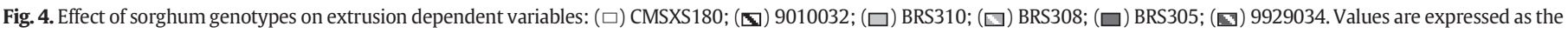

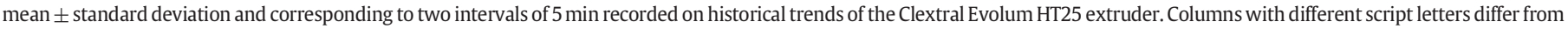
each other according to the Tukey test $(\mathrm{P}<0.05)$.

\subsubsection{Specific mechanical energy}

SME is related to the viscosity of the molten mass. Melt viscosity affects directly the resistance to work performed by screws on feed material. Polymer type and their interactions with soluble and insoluble phenolic compounds in sorghum genotypes could influence on melt/ glass transition temperatures of mass and consequently on melt viscosity. In previous studies carried out with starches extrusion, amylose and protein content affected SME values (Chaudhary, Miler, Torley, Sopade, \& Halley, 2008; de Mesa et al., 2009; Gogoi, Choudhury, \& Oswalt, 1996; Gomez et al., 1988; Zhu et al., 2010). Therefore, linear polysaccharides of high molecular weight, as amylose and fibers, increase the viscosity of the molten mass. Moreover, the great strength, tensile strength and high insolubility of these polymers allow high molecular torsion, especially under low water activity, increasing both torque and SME input.

SME varied from 1129.23 (BRS 308) to $1512.84 \mathrm{~kJ} \cdot \mathrm{kg}-^{1}$ (BRS 305). Higher SME values found for BRS 305 and CMSXS180 may be related to the presence of fine particles ( $\leq 0.3 \mathrm{~mm}$ ) (Fig. 2 ). In previous studies, it observed an inverse relationship between SME values and particle size, for corn (Carvalho, Takeiti, Onwulata, \& Pordesimo, 2010), barley (Al-Rabadi et al., 2011b; Altan, McCarthy, \& Maskan, 2009) and sorghum (Al-Rabadi et al., 2011b). In contrast, lower SME values were found to be related with coarse fractions $(\geq 1 \mathrm{~mm})$ as observed in 9929034, 9010032 and red genotypes $(\mathrm{P}<0.05)$.

Differences in SME values of sorghum genotypes could be attributed to their chemical composition (Table 1). BRS 305 presents the highest crude fiber and tannin content $(\mathrm{P}<0.05)$. Crude fiber is the insoluble fraction, rich in lignin and cellulose, which is not easily melted during the extrusion, hence it may have contributed to increase the matrix melt viscosity in the extruder. On the other hand, denaturation of proteins during extrusion leads to open loose structures, which could promote polyphenol-protein interactions, such as tannin-protein (Brennan, Brennan, Derbyshire, \& Tiwari, 2011; Emmambux \& Taylor, 2003) and ligninprotein complexes (Montaño-Leyva et al., 2013) contributing to increase both, insolubility and molecular weight of compounds.

It is interesting to observe that two white pericarp sorghums presented similar SME values to the brown pericarp $9929034(\mathrm{P} \geq 0.05)$. It is likely associated with similar amounts of protein content, reciprocal quantities of carbohydrates/crude fiber and presence of tannin content in $9929034(\mathrm{P}<0.05)$. Moreover, differences in SME values among brown genotypes could be related with reciprocal amounts of protein, crude fiber, ashes and tannin content $(\mathrm{P}<0.05)$. Red genotypes displayed the lowest SME values and presented the highest carbohydrates content $(\mathrm{P}<0.05)$.

\subsubsection{Die pressure}

Die pressure provides a direct measurement of the variation of the extrusion operation conditions, such as chemical composition, moisture content, die temperature, screw speed and mass feed rate. By increasing moisture, temperature and screw speed, and decreasing mass feed rate, die pressure is reduced (Akdogan, 1996).

The screw configuration used had two reverse screw elements CF1C with axial slots located in the ninth and tenth module of the barrel (Fig. 1), which may have contributed to building up pressure levels that varied from 3.04 to $5.19 \mathrm{MPa}$ (Fig. 4b).

Strong compressions aid to melting crystalline polymers. Reverse screw elements exert strong axial compressions which depend on their location and spacing along the barrel for building up desirable pressures at the die (Gogoi et al., 1996). Likewise, uniform flows at extruder output are related to design of the insert hole, since it establishes a nonlinear relationship between flow of extrudate and pressure drop out of the die (Chinnaswamy \& Hanna, 1987; Sokhey, Ali, \& Hanna, 1997). Reverse screw elements also contribute to fill the barrel length for build-up of a mass barrier between the feeder port and the melting zone. Thereby, it blocked the escape route of the air bubbles trapped in the melt, which were released from air-filled pores present at inter and intra granular voids during compaction, avoiding to affect the expansion properties of the melt (Cisneros \& Kokini, 2002).

CMSXS180 flour generated the highest die pressure (5.19MPa) and was different of 9010032 and red genotype flours $(P<0.05)$. The highest pressure generated by CMSXS180 flour likely can be associated with its high amounts of fine fractions. High temperature profiles and fine fractions increased both SME and die pressure, during sorghum flour extrusion (Al-Rabadi et al., 2011b).

At processing of these flours, a direct relationship between die pressure and SME input (Fig. 4) as expected was observed and in agreement with previous studies conducted in unmodified maize starches (Chaudhary et al., 2008) and sorghum flour (Al-Rabadi et al., 2011b). Differences in die pressure between pairwise of either white or red

Table 2

Physical properties of expanded extrudates from sorghum genotypes.

\begin{tabular}{|c|c|c|c|c|}
\hline \multirow[t]{2}{*}{ Genotype } & \multirow[t]{2}{*}{$\mathrm{SEI}^{\alpha}$} & Apparent density ${ }^{\alpha}$ & \multirow{2}{*}{$\frac{W_{A I}^{\beta}}{(g / g)}$} & \multirow{2}{*}{$\frac{\mathrm{WSI}^{\beta}}{(\mathrm{g} / 100 \mathrm{~g})}$} \\
\hline & & $\left(\mathrm{kg} / \mathrm{m}^{3}\right)$ & & \\
\hline CMSXS180 & $7.61 \pm 1.54^{\mathrm{ab}}$ & $94.82 \pm 0.014^{\mathrm{c}}$ & $3.91 \pm 0.06^{\mathrm{bc}}$ & $28.48 \pm 0.67^{\mathrm{a}}$ \\
\hline 9010032 & $6.64 \pm 0.64^{c}$ & $99.44 \pm 0.011^{\mathrm{c}}$ & $3.77 \pm 0.01^{\mathrm{c}}$ & $17.90 \pm 0.27^{\mathrm{e}}$ \\
\hline BRS 310 & $7.89 \pm 0.84^{\mathrm{a}}$ & $127.32 \pm 0.010^{\mathrm{b}}$ & $4.16 \pm 0.13^{a}$ & $25.53 \pm 0.57^{\mathrm{b}}$ \\
\hline BRS 308 & $7.09 \pm 0.81^{\mathrm{bc}}$ & $140.25 \pm 0.021^{\mathrm{b}}$ & $4.07 \pm 0.03^{\mathrm{ab}}$ & $22.27 \pm 0.28^{d}$ \\
\hline BRS 305 & $4.47 \pm 0.42^{\mathrm{d}}$ & $172.47 \pm 0.027^{a}$ & $3.91 \pm 0.01^{\mathrm{bc}}$ & $24.24 \pm 0.50^{c}$ \\
\hline 9929034 & $4.12 \pm 0.43^{\mathrm{d}}$ & $186.29 \pm 0.027^{\mathrm{a}}$ & $3.93 \pm 0.03^{b c}$ & $21.20 \pm 0.09^{d}$ \\
\hline
\end{tabular}

Means with different superscripts letters, within a single column, differ from each other according to the Tukey test $(\mathrm{P}<0.05)$, to compare expanded extrudates from sorghum genotypes.

${ }^{\alpha}$ Mean \pm standard deviations, $\mathrm{n}=20$

$\beta$ Mean \pm standard deviations of triplicate measurements. 
genotypes could be due to more ratios of branched polymers in the carbohydrates fraction of 9010032 and BRS 308. Die pressure is affected by unmodified starch type. Increasing amylose content, increases melt viscosity, thus the die block pressure progressively increases (Chaudhary et al., 2008).

Brown genotypes generated the lowest die pressure in similar amounts $(P \geq 0.05)$ and established an inverse relationship with their SME values. These results might reflect the presence of modified starch in their carbohydrates fraction, as well as a lubricant effect by the presence of higher fat content in these flours $(\mathrm{P}<0.05)$. Modified starch compared to unmodified starch resulted in a lower die pressure (Chaudhary et al., 2008).

\subsection{Product responses}

\subsubsection{Apparent density and sectional expansion index}

The results of apparent density and sectional expansion index (SEI) are displayed in Table 2. Apparent density varied from 95 (CMSXS180) to $186 \mathrm{~kg} \cdot \mathrm{m}^{-3}$ (9929034). Brown sorghums, rich in fiber and fat contents, showed the highest density values $(\mathrm{P}<0.05)$, whereas white sorghums presented the lowest values of density. The density of a material depends on the efficiency of packing of their molecules. Linear polymers are capable of packing more efficiently, compared to those containing branched polymers and contribute to decrease the material density (BeMiller \& Huber, 2008).

The highest SEI value was found to BRS 310 (7.89), but it was not statistically different to white sorghum CMSXS180 (7.61) ( $\mathrm{P} \geq 0.05)$. Brown genotypes presented the lowest radial expansion. Low carbohydrate content and high crude fiber as well as fat content found in brown genotypes appear to be related to low SEI values $(\mathrm{P}<0.05)$.

SEI is dependent on the elastic properties of the melt: temperature and apparent viscosity, and on die design: diameter and length (Bouzaza, Arhaliass, \& Bouvier, 1996). Melt stores energy during its flow through the die insert. Small insert diameters generate more pressure and store higher melt energy. This energy is released in the radial direction when the compressed melt emerges the die (Alvarez-Martinez et al., 1988). Moreover, small air-cells in the melt, act as nuclei for the expanding water vapor bubbles (Cisneros \& Kokini, 2002) and high pressure drops allow both, nucleation and growth of them (Akdogan, 1996; Moraru \& Kokini, 2003).

Sorghum genotypes, with high ratios of branched polymers in the carbohydrates fraction, and those low in fibers, may help to diffuse and lose water vapor released from the rupture of bubbles, during expansion process. So, it results in an open foam structure, which is important for elasticity, gas retention and cell size/cell wall thickening of the extruded product (Shukla, 1998).
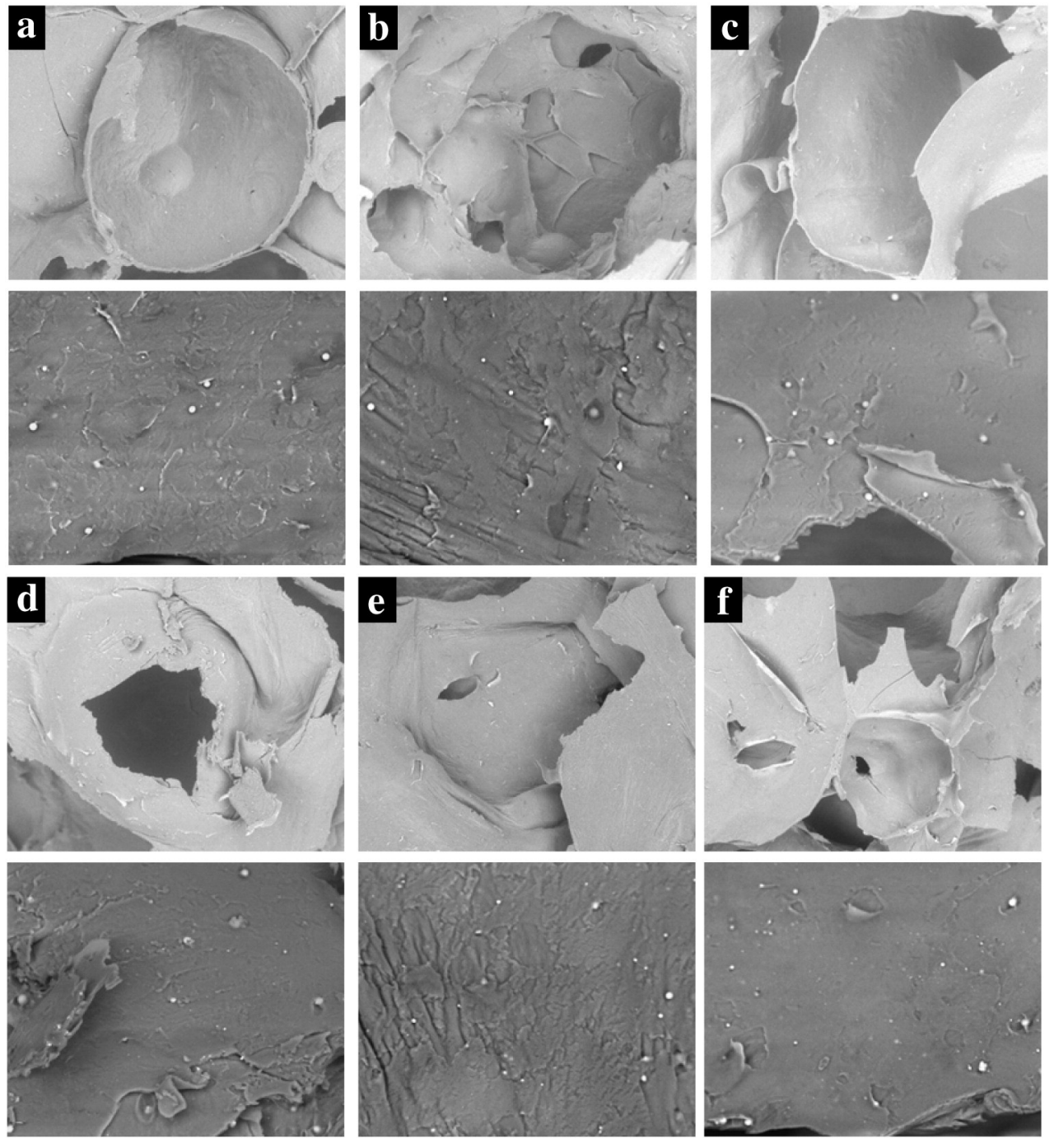

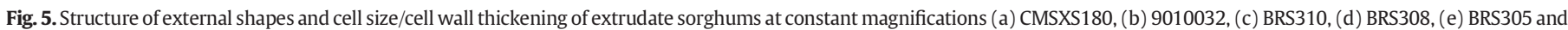
(f) 9929034 . 
White and red genotypes produced more die pressure (3.7-5.2 MPa) and SEI values (6-8). Highly expanded sorghum extrudates were produced with white decorticated sorghum of low-amylose, at $17 \%$ of extrusion moisture (Gomez et al., 1988). It suggests that brown genotypes due to its chemical composition, higher in fiber and fat content $(\mathrm{P}<0.05)$, resulted in lower die pressure and thus low in both, apparent density and SEI. The formation of fat-starch complex during the extrusion process is being reported to decrease the ability of starch to expand (Bhatnagar \& Hanna, 1994).

\subsubsection{Water absorption and water solubility indexes}

The results of WAI and WSI are shown in Table 2. Although the results showed statistical difference among the extruded sorghum, the values of WAI did not present substantial discrepancy. CMSXS180 flour presented low WAI and high WSI (3.91 g/g and 28.48g/100 g). According to Sriburi, Hill, and Barclay (1999), these characteristics would indicate that starch has undergone extensive conversion. Red genotypes absorbed slight higher water content by weight of insoluble solids in similar amounts than others $(P \geq 0.05)$. In contrast, BRS $310(25.53 \mathrm{~g} / 100 \mathrm{~g})$ released more soluble solids than BRS 308 ( $22.27 \mathrm{~g} / 100 \mathrm{~g})$. It could be understood that red genotypes underwent lower starch conversion, which corroborated to low SME values, indicating lower starch broken down. Brown genotypes absorbed intermediate water content, but 9929034 flour $(21.20 \mathrm{~g} / 100 \mathrm{~g})$ was less soluble than BRS 305 (24.24 g/100 g), which might be influenced by tannin content $(\mathrm{P}<0.05)$ and intrinsic characteristics such as degree of branched polymers. Sorghum arabinoxylans were reported to be highly branched, so they contribute to the capacity to retain water and to the ability to retain gas in the dough (Nandini \& Salimath, 2001). Another fact could be related to some transformation of insoluble to soluble fiber (Ralet, Thibault, \& Della Valle, 1990).

Absorption of water molecules starts by fixing it on polar zones of the polymers, until it achieves their swelling. Swelling properties involve the increased hydrogen bonding between water molecules with hydroxyl groups in the starch polymers or with polar side chains in the molecular surface of proteins. Fiber has a lower swelling potential due to higher insolubility (BeMiller \& Huber, 2008).

\subsection{Microstructural characteristics}

SEM microphotographs of sorghum extrudates (Fig. 5) showed differentiated cellular structure characteristics between them. The CMSXS180 and BRS 310 extrudates (Fig. 5a,c) presented similar cell sizes and were higher than brown extrudates (Fig. 5e,f). The BRS310 extrudate showed irregular cell membranes with regard to CMSXS180. The 9010032 extrudate (Fig. 5b) presented the higher levels of air-cell coalescence with regard to the others. The cell wall surfaces of 9010032 and BRS 305 were relatively rough (Fig. 5b,e), with respect to their counterparts, genotypes of the same pericarp color (Fig. 5a,f). Moreover, red genotypes showed lamellar protrusions on cell wall surfaces (Fig. 5c,d). The CMSXS180 and BRS 310 extrudates presented low-thickness cell wall, indicating fragile structure, which was correlated to the high SEI and WSI in both genotypes, showing high degree of starch conversion.

In all sorghum extrudates were observed with spherical granules of variable size, distributed on cell wall surfaces. These spherical bodies could be associated with resistant starch formed during extrusion process.

\section{Conclusion}

Extrusion of whole flours of sorghum under the same operating conditions resulted in a significant effect on dependent variables and on the physicochemical properties, due to different chemical compositions, fiber and tannin content, and between sorghum genotypes processed. Light brown genotypes generated the lowest melt pressure and SEI values, low WAI and the highest apparent density values, differing between them in SME and WSI values. Red genotypes presented the lowest SME, the highest WAI and intermediate apparent density values. White genotypes presented intermediate SME, low WAI and the lowest apparent density values. Between pairwise of either white or red genotypes, they differed in melt pressure, SEI and WSI values.

Red genotypes, low in tannin and fiber content, are relatively easy to be extruded. These findings suggest the potential use of the BRS310 genotype to formulate instantaneous drinks, due to its easy water diffusion at ambient temperature. Moreover, the BRS308 and 9929034 genotypes, the latter being high in tannin and fiber contents, could be used to produce with whole grain sorghum breakfasts, due to their low solubility in warm water, with improved nutritional quality in terms of fiber and antioxidant contents.

\section{Acknowledgments}

The authors thank the scholarships granted by Ford Foundation to Jhony W. Vargas-Solórzano and by CNPq to Carlos W. P. Carvalho and José L. R. Ascheri.

\section{References}

Akdogan, H. (1996). Pressure, torque, and energy responses of a twin screw extruder at high moisture contents. Food Research International, 29(5-6), 423-429.

Al-Rabadi, G. J., Torley, P. J., Williams, B.A., Bryden, W. L., \& Gidley, M. J. (2011a). Effect of extrusion temperature and pre-extrusion particle size on starch digestion kinetics in barley and sorghum grain extrudates. Animal Feed Science and Technology, 168(3-4), 267-279.

Al-Rabadi, G. J., Torley, P. J., Williams, B.A., Bryden, W. L., \& Gidley, M. J. (2011b). Particle size of milled barley and sorghum and physico-chemical properties of grain following extrusion. Journal of Food Engineering, 103(4), 464-472.

Altan, A., McCarthy, K. L., \& Maskan, M. (2009). Effect of screw configuration and raw material on some properties of barley extrudates. Journal of Food Engineering, 92(4), 377-382.

Alvarez-Martinez, L., Kondury, K. P., \& Harper, J. M. (1988). A general model for expansion of extruded products. Journal of Food Science, 53(2), 609-615.

Anderson, J. C., Conway, H. F., Pfeifer, V. F., \& Griffin, E. L. (1969). Gelatinization of corn grits by roll and extrusion cooking. Cereal Science Today, 14(1), 4-12.

Anderson, J. C., \& Jones, B.D. (1999). Principal factor analysis of extruded sorghum and peanut bar changes during accelerated shelf-life studies. Journal of Food Science, 64(6), 1059-1063.

AOAC (2005). Official methods of analysis of AOAC International (18th ed.)Gaithersburg: AOAC International.

Arranz, S., \& Saura Calixto, F. (2010). Analysis of polyphenols in cereals may be improved performing acidic hydrolysis: A study in wheat flour and wheat bran and cereals of the diet. Journal of Cereal Science, 51(3), 313-318.

Awika, J. M., \& Rooney, L. W. (2004). Sorghum phytochemicals and their potential impact on human health. Phytochemistry, 65(9), 1199-1221.

BeMiller, J. N., \& Huber, K. C. (2008). Carbohydrates. In S. Damodaran, K. L. Parkin, \& O. R. Fennema (Eds.), Fennema's food chemistry (pp. 75-130) (4th ed.). Boca Raton: CRC Press.

Berk, Z. (2009). Extrusion. Food process engineering and technology (pp. 333-350). London: Academic Press.

Berrios, J. J., Ascheri, J. L. R., \& Losso, J. N. (2013). Extrusion processing of dry beans and pulses. In M. Siddiq, \& M.A. Uebersax (Eds.), Dry beans and pulses (pp. 185-203). Iowa: John Wiley \& Sons.

Bhatnagar, S., \& Hanna, M.A. (1994). Amylose-lipid complex formation during single-screw extrusion of various corn starches. Cereal Chemistry, 71(6), 582-586.

Bouzaza, D., Arhaliass, A., \& Bouvier, J. M. (1996). Die design and dough expansion in low moisture extrusion-cooking process. Journal of Food Engineering, 29(2), 139-152.

Brennan, C., Brennan, M., Derbyshire, E., \& Tiwari, B. K. (2011). Effects of extrusion on the polyphenols, vitamins and antioxidant activity of foods. Trends in Food Science E Technology, 22(10), 570-575.

Burns, R. E. (1971). Method for estimation of tannin in grain sorghum. Agronomy Journal, 63(3), 511-512.

Carvalho, C. W. P., Takeiti, C. Y., Onwulata, C. I., \& Pordesimo, L. O. (2010). Relative effect of particle size on the physical properties of corn meal extrudates: Effect of particle size on the extrusion of corn meal. Journal of Food Engineering, 98(1), 103-109.

Chaudhary, A. L., Miler, M., Torley, P. J., Sopade, P. A., \& Halley, P. J. (2008). Amylose content and chemical modification effects on the extrusion of thermoplastic starch from maize. Carbohydrate Polymers, 74(4), 907-913.

Chinnaswamy, R., \& Hanna, M.A. (1987). Nozzle dimension effects on the expansion of extrusion cooked corn starch. Journal of Food Science, 52(6), 1746-1747.

Cisneros, F. H., \& Kokini, J. L. (2002). A generalized theory linking barrel fill length and air bubble entrapment during extrusion of starch. Journal of Food Engineering, 51(2), 139-149. 
de Mesa, N. J. E., Alavi, S., Singh, N., Shi, Y. -C., Dogan, H., \& Sang, Y. (2009). Soy protein-fortified expanded extrudates: Baseline study using normal corn starch. Journal of Food Engineering, 90(2), 262-270.

de Mesa-Stonestreet, N. J., Alavi, S., \& Gwirtz, J. (2012). Extrusion-enzyme liquefaction as a method for producing sorghum protein concentrates. Journal of Food Engineering, 108(2), 365-375.

Deshpande, S. S., \& Cheryan, M. (1985). Evaluation of vanillin assay for tannin analysis of dry beans. Journal of Food Science, 50(4), 905-910.

Do an, H., \& Karwe, M. V. (2003). Physicochemical properties of quinoa extrudates. Food Science and Technology International, 9(2), 101-114.

Dykes, L., \& Rooney, L. W. (2006). Sorghum and millet phenols and antioxidants. Journal of Cereal Science, 44(3), 236-251.

Dykes, L., Seitz, L. M., Rooney, W. L., \& Rooney, L. W. (2009). Flavonoid composition of red sorghum genotypes. Food Chemistry, 116(1), 313-317.

Earp, C. F., McDonough, C. M., \& Rooney, L. W. (2004). Microscopy of pericarp development in the caryopsis of Sorghum bicolor (L.) Moench. Journal of Cereal Science, 39(1), 21-27.

Emmambux, N. M., \& Taylor, J. R. N. (2003). Sorghum kafirin interaction with various phenolic compounds. Journal of the Science of Food and Agriculture, 83(5), 402-407.

Falcone, R. G., \& Phillips, R. D. (1988). Effects of feed composition, feed moisture, and barrel temperature on the physical and rheological properties of snack-like products prepared from cowpea and sorghum flours by extrusion. Journal of Food Science, 53(5), 1464-1469.

Fan, J., Mitchell, J. R., \& Blanshard, J. M. V. (1996). The effect of sugars on the extrusion of maize grits: I. The role of the glass transition in determining product density and shape. International Journal of Food Science \& Technology, 31(1), 55-65.

FAOSTAT (2013). FAO Statistics Division 2013. Food and Agriculture Organization of the United Nations.

Fapojuwo, O. O., Maga, J. A., \& Jansen, G. R. (1987). Effect of extrusion cooking on in vitro protein digestibility of sorghum. Journal of Food Science, 52(1), 218-219.

Gogoi, B. K., Choudhury, G. S., \& Oswalt, A. J. (1996). Effects of location and spacing of reverse screw and kneading element combination during twin-screw extrusion of starchy and proteinaceous blends. Food Research International, 29(5-6), 505-512.

Gomez, M. H., Waniska, R. D., Rooney, L. W., \& Lusas, E. W. (1988). Extrusion-cooking of sorghum containing different amounts of amylose. Journal of Food Science, 53(6), $1818-1822$.

Lai, L. S., \& Kokini, J. L. (1991). Physicochemical changes and rheological properties of starch during extrusion. (A review). Biotechnology Progress, 7(3), 251-266.

Mahasukhonthachat, K., Sopade, P. A., \& Gidley, M. J. (2010). Kinetics of starch digestion and functional properties of twin-screw extruded sorghum. Journal of Cereal Science, 51(3), 392-401.

Meera, M. S., Bhashyam, M. K., \& Ali, S. Z. (2011). Effect of heat treatment of sorghum grains on storage stability of flour. LWT - Food Science and Technology, 44(10), 2199-2204.

Méndez-Albores, A., Veles-Medina, J., Urbina-Álvarez, E., Martínez-Bustos, F., \& Moreno-Martínez, E. (2009). Effect of citric acid on aflatoxin degradation and on functional and textural properties of extruded sorghum. Animal Feed Science and Technology, 150(3-4), 316-329.

Montaño-Leyva, B., Silva, G. D. G., Gastaldi, E., Torres-Chávez, P., Gontard, N., \& Angellier-Coussy, H. (2013). Biocomposites from wheat proteins and fibers: Structure/ mechanical properties relationships. Industrial Crops and Products, 43, 545-555.

Moraes, É. A., Queiroz, V. A. V., Shaffert, R. E., Costa, N. M. B., Nelson, J.D., Ribeiro, S. M. R. et al. (2012). In vivo protein quality of new sorghum genotypes for human consumption. Food Chemistry, 134(3), 1549-1555.

Moraru, C. I., \& Kokini, J. L. (2003). Nucleation and expansion during extrusion and microwave heating of cereal foods. Comprehensive Reviews in Food Science and Food Safety 2(4), 147-165.

Mukisa, I. M., Muyanja, C. M. B. K., Byaruhanga, Y. B., Schüller, R. B., Langsrud, T., \& Narvhus, J. A. (2012). Gamma irradiation of sorghum flour: Effects on microbial inactivation, amylase activity, fermentability, viscosity and starch granule structure. Radiation Physics and Chemistry, 81(3), 345-351.

Nandini, C. D., \& Salimath, P. V. (2001). Structural features of arabinoxylans from sorghum having good roti-making quality. Food Chemistry, 74(4), 417-422.

Peyron, S., Chaurand, M., Rouau, X., \& Abecassis, J. (2002a). Relationship between bran mechanical properties and milling behaviour of durum wheat (Triticum durum Desf.). Influence of tissue thickness and cell wall structure. Journal of Cereal Science, 36(3), 377-386.

Peyron, S., Surget, A., Mabille, F., Autran, J. C., Rouau, X., \& Abecassis, J. (2002b). Evaluation of tissue dissociation of durum wheat grain (Triticum durum Desf.) generated by the milling process. Journal of Cereal Science, 36(2), 199-208.

Ralet, M. C., Thibault, J. F., \& Della Valle, G. (1990). Influence of extrusion-cooking on the physico-chemical properties of wheat bran. Journal of Cereal Science, 11(3), 249-259.

Shukla, T. P. (1998). Critical chemistry of extrusion processing of grains. Cereal Foods World, 43.

Sokhey, A. S., Ali, Y., \& Hanna, M.A. (1997). Effects of die dimensions on extruder performance. Journal of Food Engineering, 31(2), 251-261.

Sriburi, P., Hill, S. E., \& Barclay, F. (1999). Depolymerisation of cassava starch. Carbohydrate Polymers, 38(3), 211-218.

Sullins, R. D., \& Rooney, L. W. (1975). Light and scanning electron microscopic studies of waxy and nonwaxy endosperm sorghum varieties. Cereal Chemistry, 52.

Vázquez-Araújo, L., Chambers Iv, E., \& Cherdchu, P. (2012). Consumer input for developing human food products made with sorghum grain. Journal of Food Science, 77(10), S384-S389.

Wu, L., Huang, Z., Qin, P., \& Ren, G. (2012). Effects of processing on phytochemical profiles and biological activities for production of sorghum tea. Food Research International, 53(2), 678-685.

Youssef, A.M. M., Moharram, Y. G., Moustaffa, E. K., Bolling, H., El-Baya, A., \& Harmuth, A. E. (1990). New extruded products from sorghum. Food Chemistry, 37(3), 189-199.

Zhu, L. -J., Shukri, R., de Mesa-Stonestreet, N. J., Alavi, S., Dogan, H., \& Shi, Y. -C. (2010) Mechanical and microstructural properties of soy protein - High amylose corn starch extrudates in relation to physiochemical changes of starch during extrusion. Journa of Food Engineering, 100(2), 232-238. 